\title{
Association of leptin receptor gene polymorphisms and meta-inflammation markers with metabolically unhealthy obesity in children
}

\author{
A. E. Abaturov ${ }^{A, E, D, F}$, A. O. Nikulina ${ }^{D} * B, C, D, F$
}

Dnipro State Medical University, Ukraine

A - research concept and design; B - collection and/or assembly of data; C - data analysis and interpretation; D - writing the article; $\mathrm{E}$ - critical revision of the article; $\mathrm{F}$ - final approval of the article

Key words:

leptin

receptor gene, polymorphism, interleukin-6, meta-inflammation, obesity, children

\section{Zaporozhye} medical journal 2021; 23 (5), 696-702

*E-mail: anna.nikulina.201381@ gmail.com
The aim: to study the contribution of single-nucleotide polymorphisms (SNP) of the leptin receptor (LEPR) gene and meta-inflammation markers to the formation of metabolically unhealthy obesity (MUO) in children.

Materials and methods. A total of 109 obese children aged 6-18 years were examined. Based on the recommendations of the National Heart, Lung, and Blood Institute (NHLBI), 2 observation groups were formed. The main group $(n=56)$ was represented by patients with MUO. The control group $(n=53)$ comprised children with metabolically healthy obesity $(M H O)$. Serum levels of interleukin-1 $\beta$ (IL-1 $\beta$ ) were measured using a chemiluminescent immunoassay (CLIA) method, interleukin-6, leptin, adiponectin - by enzyme-linked immunosorbent assay (ELISA) and the serum level of C-reactive protein were quantified by latex turbidimetric method (Synevo, Ukraine). The method of next-generation sequencing (NGS) (CeXGat, Germany) was used to identify LEPR SNP. Statistical methods were used: analysis of variance, Spearman's correlation analysis and multiple discriminant analysis.

Results. In obese children aged 6 to 18 years, there was an increase in pro-inflammatory adipokines IL-6 and leptin and a decrease in anti-inflammatory adiponectin. Statistically significant changes in these indicators were more expressed in the main group: IL-6 - $7.4 \pm 0.5 \mathrm{pg} / \mathrm{ml}(\rho=0.65 ; \mathrm{P} \leq 0.001)$; adiponectin $-3.9 \pm 0.8 \mu \mathrm{g} / \mathrm{ml}(\rho=-0.27 ; \mathrm{P}=0.007)$ among all the children examined, leptin in girls $-47.8 \pm 4.4 \mathrm{ng} / \mathrm{ml}(\rho=-0.28 ; P=0.003)$ compared with the results of patients in the control group: IL-6 - $4.3 \pm 0.3 \mathrm{pg} / \mathrm{ml}$, adiponectin $-7.7 \pm 2.4 \mu \mathrm{g} / \mathrm{ml}$, leptin in girls $-32.5 \pm 4.3 \mathrm{ng} / \mathrm{ml}, \mathrm{P} \leq 0.05$. The most important in the development of MUO were the following SNP of the LEPR gene: $r 53790435\left(\mathrm{Ci}_{\text {MUO }}=0.939\right), \mathrm{rs} 2186248\left(\mathrm{Ci}_{\text {MUO }}=0.862\right)$, $P<0.05$. A strong correlation was found between MUO and serum IL-6 level $(\rho=0.7)$, LEPR SNP rs3790435 $(\rho=0.7)$, basal hyperinsulinemia $(\rho=0.72) ; P \leq 0.001$. The risk of IL-6-dependent meta-inflammation in the presence of SNP rs3790435 of the LEPR gene: $\mathrm{OR}=17.11 ; 95 \% \mathrm{Cl} 2.8-20.4$

Conclusions. Meta-inflammation in MUO is IL-6-dependent. Among the 10 SNPs of the LEPR gene that we identified, SNP rs3790435 of the LEPR gene has a strong association with the formation of MUO. SNP rs2186248 LEPR was described by us for the first time when it was found in $94.1 \%$ of obese children, but it was characterized by the presence of a weak association with MUO.
Киючові слова: ген, мептиновий рецептор, поліморфізм, інтерлейкін-6, метазапалення, ожиріння, Аіти.

Запорізький медичний журнал 2021. T. 23, № 5(128) C. 696-702

\section{Асоціація поліморфізмів гена мептинового рецептора, маркерів метазапалення в дітей із метаболічно нездоровим ожирінням}

\section{0. Є. Абатуров, А. 0. Нікуліна}

Мета роботи - вивчити внесок однонуклеотидних поліморфізмів гена лептинового рецептора та маркерів метазапалення в формування метаболічно нездорового ожиріння в дітей.

Матеріали та методи. Обстежили 109 дітей віком 6-18 років з ожирінням. Згідно з рекомендаціями National Heart, Lung, and Blood Institute (NHLBI), сформували 2 групи спостереження: основна ( $\mathrm{n}=56)$ - пацієнти з метаболічно нездоровим

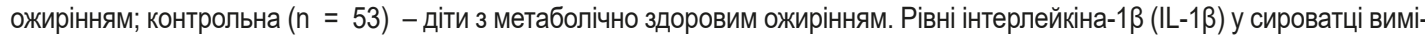
рювали за допомогою методу хемілюмінесцентного імуноаналізу (CLIA), IL-6, лептин, адипонектин досліджували методом імуноферментного аналізу (ELISA), а рівень C-реактивного білка в сироватці визначали кількісно за допомогою латексного турбідиметричного методу (Synevo, Україна). Для виявлення однонуклеотидних поліморфізмів гена лептинового рецептора застосовували метод геномного секвенування нової генерації, NGS (CeXGat, ФPH). Використовували статистичні методи: варіаційний аналіз, кореляційний аналіз Спірмена та множинний дискримінантний аналіз.

Результати. У дітей віком 6-18 років з ожирінням визначили підвищення прозапальних адипокінів IL-6 і лептину, а також зниження протизапального адипонектину. Статистично значущі зміни цих показників зафіксували основній групі: IL-6 $7,4 \pm 0,5$ пг/мл ( $\rho=0,65 ; p \leq 0,001) ;$ адипонектин $-3,9 \pm 0,8$ мкг/мл ( $\rho=-0,27 ; p=0,007)$ в усіх обстежених; лептин у дівчат $-47,8 \pm 4,4$ нг/мл ( $\rho=-0,28 ; p=0,003)$. Результати пацієнтів контрольної групи: IL-6 - 4,3 \pm 0,3 пг/мл, адипонектин $-7,7 \pm 2,4$ мкг/мл, лептин у дівчат $-32,5 \pm$ 4,3 мкг/мл, p $\leq$ 0,05. Найбільше значення в розвитку метаболічно нездорового ожиріння мають такі однонуклеотидні поліморфізми гена лептинового рецептора: $\mathrm{rs}_{3790435}\left(\mathrm{Ci}_{\text {мио }}=0,939\right)$, rs2186248 $\left(\mathrm{Ci}_{\mathrm{muo}_{\mathrm{o}}}=0,862\right), \mathrm{p}<0,05$. Виявили сильний кореляційний зв'язок між метаболічно нездоровим ожирінням і рівнем IL-6 ( $\rho=0,7)$, однонуклеотидним поліморфізмом rs3790435 гена лептинового рецептора $(\rho=0,7)$, базальною гіперінсулінемією $(\rho=0,72), p \leq 0,001$. Ризик формування IL-6-залежного метазапалення за наявності однонуклеотидного поліморфізму rs3790435 гена лептинового рецептора - ВШ = 17,11; 95 \% ДІ 2,8-20,4. 
Висновки. Метазапалення при метаболічно нездоровому ожирінні має IL-6-залежний характер. Серед виявлених 10 однонуклеотидних поліморфізмів гена лептинового рецептора сильну асоціацію з формуванням метаболічно нездорового ожиріння має однонуклеотидний поліморфізм rs3790435 гена лептинового рецептора. Однонуклеотидний поліморфізм rs2186248 гена лептинового рецептора описаний уперше при виявленні у 94,1% дітей з ожирінням, але характеризується наявністю слабкої асоціації з метаболічно нездоровим ожирінням.

\section{Ассоциация полиморфизмов гена лептинового рецептора, маркеров метавоспаления у детей с метаболически нездоровым ожирением}

\section{А. Е. Абатуров, А. А. Никулина}

Цель работы - изучить вклад однонуклеотидных полиморфизмов гена лептинового рецептора и маркеров метавоспаления в формирование метаболически нездорового ожирения у детей.

Материалы и методы. Обследовали 109 детей в возрасте 6-18 лет с ожирением. Согласно рекомедациям National Heart, Lung, and Blood Institute (NHLBI), сформировали 2 группы наблюдения: основная ( $\mathrm{n}=56$ ) - пациенты с метаболически нездоровым ожирением; контрольная ( $\mathrm{n}=53$ ) - дети с метаболически здоровым ожирением. Уровни интерлейкина-1 $\beta$ (IL-1ß) в сыворотке измеряли с помощью метода хемилюминесцентного иммуноанализа (CLIA), IL-6, лептин, адипонектин исследовали методом иммуноферментного анализа (ELISA), а уровень C-реактивного белка в сыворотке определяли количественно с помощью латексного турбидиметрического метода (Synevo, Украина). Для выявления однонуклеотидных полиморфизмов гена лептинового рецептора применяли метод геномного секвенирования нового поколения, NGS (CeXGat, ФРГ). Использовали статистические методы: вариационный анализ, корреляционный анализ Спирмена и множественный дискриминантный анализ.

Результаты. У детей в возрасте 6-18 лет с ожирением отмечено повышение провоспалительных адипокинов IL-6, лептина и снижение противовоспалительного адипонектина. Статистически значимые изменения этих показателей более выражены в основной группе: IL-6 - 7,4 $\pm 0,5$ пг/мл ( $\rho=0,65 ; p \leq 0,001)$; адипонектин $-3,9 \pm 0,8$ мкг/мл $(\rho=-0,27 ; p=0,007)$ у всех обследованных, лептин у девочек $-47,8 \pm 4,4$ нг/мл $(\rho=-0,28 ; p=0,003)$. Результаты пациентов контрольной группы: IL-6 - 4,3 \pm 0,3 пг/мл, адипонектин - 7,7 $\pm 2,4$ мкг/мл, лептин у девочек $-32,5 \pm 4,3$ мкг/мл, p $\leq 0,05$. Наибольшее значение в развитии метаболически нездорового ожирения имеют такие однонуклеотидные полиморфизмы гена лептинового рецептора: rs3790435 ( $\left.\mathrm{Ci}_{\text {мuо }}=0,939\right)$, rs2186248 ( $\left.\mathrm{Ci}_{\text {мио }}=0,862\right), \mathrm{p}<0,05$. Установлена сильная корреляционная связь между метаболически нездоровым ожирением и уровнем сывороточного IL-6 ( $\rho=0,7)$, однонуклеотидным полиморфизмом rs3790435 гена лептинового рецептора $(\rho=0,7)$, базальной гиперинсулинемией $(\rho=0,72) ; p \leq 0,001$. Риск формирования IL-6-зависимого метавоспаления при наличии однонуклеотидного полиморфизма rs3790435 гена лептинового рецептора - ОШ $=17,11 ; 95 \%$ ДИ 2,8-20,4

Выводы. Метавоспаление при метаболически нездоровом ожирении имеет IL-6-зависимый характер. Среди установленных 10 однонуклеотидных полиморфизмов гена лептинового рецептора сильную ассоциацию с формированием метаболически нездорового ожирения имеет однонуклеотидный полиморфизм rs3790435 гена лептинового рецептора. Однонуклеотидный полиморфизм rs2186248 гена лептинового рецептора описан впервые при обнаружении у 94,1 \% детей с ожирением, но характеризовался наличием слабой ассоциации с метаболически нездоровым ожирением.

Obesity in children, adolescents, and subsequently in adults is one of the most serious public health problems in the $21 \mathrm{st}$ century. The spread of obesity is pandemic. The number of children and adolescents (5-19 years) living with obesity, predicted by the early 2025, will be 206 million [1]. Molecular genetic features of obesity-induced meta-inflammation are of particular practical interest in the context of an obesity pandemic in the human population, due to the fact that it is the obesity phenotype that determines the degree of cardiovascular risk [2]. The phenotype of metabolically healthy obesity (MHO) is defined by The American Academy of Pediatrics [3] as a condition in which, despite the excess of physiological body weight over the 95th percentile, there are no risk factors such as insulin resistance, dyslipidemia and arterial hypertension, in contrast with the phenotype of metabolically unhealthy obesity (MUO) [4-6].

The development of meta-inflammation in MUO is characterized by a change in the spectrum of products synthesized by adipocytes due to excessive fat accumulation as a result of an increase in the synthesis of pro-inflammatory cytokines and a decrease in the level of adiponectin secretion. The previously presented data on the difference in the pathophysiological processes of the meta-inflammation formation in $\mathrm{MHO}$ and $\mathrm{MUO}$ require further study on the role of candidate genes responsible for the formation of insulin resistance $[7,8]$. One of the main genomic representatives involved in the regulation of energy consumption is the leptin receptor (LEPR) gene. It has been proven that SNPs of the LEPR gene are found in $21.9 \%$ of patients with various obesity phenotypes and lead to a decrease in the activity of the anorexigenic cascade and deregulation of the LEP/ LEPR axis, increased food intake and fat deposition $[9,10]$.

Analysis of the scientometric PubMed database showed that the most studied association between obesity and type 2 diabetes are the following SNPs of the LEPR gene: rs3790435 [11] and missense mutations rs 1137100 [12,13], rs1137101 [14,15], rs1805094 [16], rs8179183 [17], which are located in gene regions encoding functionally significant domains of the LEPR protein.

Genetic studies have demonstrated a high degree of association of non-synonymous polymorphisms of the LEPR gene with the development of monogenic obesity [18]. However, data on the role of intron mutations in the formation of excess fat mass are presented in isolated works and only in some variants $[19,20]$. In addition, to present, there are no studies demonstrating the relationship between the LEPR SNP and the development of meta-inflammation in various obesity phenotypes.
Ключевые слова:

ген, лептина рецепторы, полиморфизм, интерлейкин-6, метавоспаление, ожирение, Аети.

\section{Запорожский} медицинский журнал 2021. T. 23, № 5(128) C. $696-702$ 
Using new generation of the complete genome sequencing method opens the potential for studying the role of SNP variants of the LEPR gene and demonstrates the different functional significance of these conformations in the central regulation of energy balance in polygenic obesity [21]. Isolation of the key pro-inflammatory factors associated with obesity will allow the use of drug-induced silencing in personalized prevention and treatment of metabolic disorders that pose a threat to the health and life of patients.

\section{Aim}

To study the contribution of SNP of the LEPR gene and meta-inflammation markers to the formation of MUO in children.

\section{Material and methods}

All the procedures performed in studies involving human participants were in accordance with the ethical standards of the Institutional and/or National Research Committee and with the 2000 Helsinki declaration (52nd WMA General Assembly, Edinburgh, Scotland) and its later amendments or comparable ethical standards. The submissions were reviewed by the Ethics Committee of Dnipro State Medical University (meeting minutes No. 7 of December 11, 2019 and meeting minutes No. 5 of September 3, 2020).

An informed consent was obtained from each individual participant enrolled in the study.

At the Children's Endocrinology Department of the Communal Non-profit Enterprise "Dnipro City Clinical Hospital No. 9" of the Dnipro City Council, 109 children aged 6-18 years (mean age $12.24 \pm 0.14$ ) with a diagnosis of obesity were examined. To verify the diagnosis, the classification of obesity recommended in clinical practice was used: Order of the Ministry of Health of Ukraine No. 254 of 27.04.2006 "Protocol for the provision of medical care to obese children".

Inclusion criteria: body mass index (BMI) exceeding the 95th percentile or $2 \mathrm{SD}$ [22].

Exclusion criteria: monogenic and secondary forms of obesity; hereditary syndromes accompanied by obesity; diseases, the treatment of which requires the use of medications that affect the metabolism of carbohydrates and lipids; pregnancy.

The main group $(n=56)$ included patients with the MUO phenotype, the control group ( $n=53$ ) comprised children with the $\mathrm{MHO}$ phenotype. The recommendations of the NHLBI expert group (USA) were used as the criteria for MUO in children and adolescents [4].

For inclusion in the main study group, the presence of abdominal obesity and two of the presented criteria were taken into account: 1) fasting glycemia $\geq 5.6 \mathrm{mmol} / \mathrm{L}$ [23]; 2) high-density lipoprotein $(\mathrm{HDL}) \leq 1.03 \mathrm{mmol} / \mathrm{L} ; 3)$ triacylglyceride (TAG) $\geq 1.7 \mathrm{mmol} / \mathrm{L} ; 4)$ systolic blood pressure (SBP) above the 90th percentile for a given age, sex and height [6]. The abdominal type of obesity was determined according to the consensus of the International Diabetes Federation (IDF), based on the waist circumference exceeding the $90^{\text {th }}$ percentile for children aged $6-15$ years or more than $94 \mathrm{~cm}$ for boys aged $16-18$ years and more than $80 \mathrm{~cm}$ for girls aged $16-18$ years [24-26].
To study the violation of carbohydrate metabolism, the level of basal glycemia and insulinemia was determined by immunochemical testing with electrochemiluminescence detection (ECLIA), followed by calculation of the generally accepted marker of insulin resistance (HOMA-IR). An increase in insulin resistance was observed at HOMA-IR $>95^{\text {th }}$ percentile according to the percentile curves recommended by the IDEFICS consortium for the European population in accordance with the age and sex of a child [27,28].

To study lipid metabolism disorders, the HDL and TAG levels were determined by the enzymatic - colorimetric method using kits from Roche Diagnostics (Switzerland) on a Cobas 6000 analyzer. The measurements were carried out in a certified Synevo Laboratory (Dnipro, Ukraine). The study material was venous blood.

To study the role of pro-inflammatory markers in the development of meta-inflammation in children with obesity, the serum levels of interleukin- $1 \beta(\mathrm{IL}-1 \beta)$, interleukin- 6 (IL-6), C-reactive protein (CRP), leptin, and adiponectin were determined in the certified Synevo Laboratory (Dnipro, Ukraine).

$\mathrm{IL}-1 \beta$ was detected by the immunochemical method with chemiluminescence immunoassay (CLIA). Analyzer and test-system: Immulite (Siemens AG), Germany. The reference value of IL- $1 \beta$ level was $0-5 \mathrm{pg} / \mathrm{ml}$. IL- 6 was determined by an enzyme-linked immunosorbent assay (ELISA) using a Cobas 6000/Cobas 8000 kit provided by Roche Diagnostics (Switzerland). The reference value of IL-6 level was $1.5-7.0 \mathrm{pg} / \mathrm{ml}$. The level of CRP was measured using the turbidimetric immunoassay method. Analyzer and test-system: Cobas 6000 (with 501 modules), Roche Diagnostics (Switzerland). The CRP level of $0-5 \mathrm{mg} / \mathrm{dl}$ was considered the reference value. Leptin was determined using ELISA. Analyzer and test system: Tecan Sunrise, LDN (Germany). The reference value of leptin level for boys was 2.0-5.6 ng/ml, for girls - 3.7-11.1 ng/ml. Adiponectin was tested using ELISA. Analyzer and test system: Mediagnost $\mathrm{GmbH}$ (Germany). Interpretation of the results was carried out as follows: low cardiovascular risk - more than 10 $\mu \mathrm{g} / \mathrm{ml}$; moderate cardiovascular risk - 7-10 $\mu \mathrm{g} / \mathrm{ml}$; high cardiovascular risk - 4-7 $\mu \mathrm{g} / \mathrm{ml}$; very high cardiovascular risk - less than $4 \mu \mathrm{g} / \mathrm{ml}$.

To study the contribution of SNP variants of the LEPR gene to the formation of MUO, a molecular genetic examination was conducted using new generation of the complete genome sequencing (NGS) method according to the American College of Medical Genetics and Genomics (ACMG) recommendations [29]. We examined 35 patients (18 children from the main group and 17 children from the control group) aged 6-18 years with obesity via venous blood sampling in a certified CeXGat Laboratory (Tubingen, Germany) using the Illumina CSPro® Certified service provider platform. The mean age of patients in the study groups was $12.06 \pm 1.25$ years. The proportion of boys in the main group was $61.1 \pm 5.5 \%(11 / 18)$, while in the control group, the proportion of boys among the study population was $47.06 \pm 4.1 \%(8 / 17), P \geq 0.05$. The mean amount of DNA $(\mu \mathrm{g})$ in samples was 0.875 . Library Preparation: Quantity used 50 ng. Library Preparation Kit: Twist Human Core Exome plus Kit (Twist Bioscience). Sequencing parameters: NovaSeq 6000; $2 \times 100$ bp. QC values of sequencing, Q30 value: $96.07 \%$. 
Bioinformatic analysis - demultiplexing of the sequencing reads was performed with Illumina bcl2fastq (version 2.20). Adapters were trimmed with Skewer, version 0.2.2 [30]. DNA-Seq: trimmed raw reads were aligned to the human reference genome (hg19-cegat) using the BurrowsWheeler Aligner, BWA - mem version 0.7.17-cegat [31]. $A B R A$, version 2.18 [32] was used for local restructuring of readings in target regions to improve more accurate detection of indels in the genome during mutagenesis. Proprietary readout tools, alignment with more than one locus with the same alignment score, were used; duplicate reads were discarded.

Variant calling: additional proprietary software was used to detect variants of polymorphisms, including variants with low frequencies (Observed frequency of the alternative allele in the range, OFA up to $2 \%$ of sequenced readings). The mutation variants were annotated based on various publicly available databases (Ensembl v100, RefSeq Curated (20200723), CCDS r22, dbSNP154, GnomAD 2.1 (exonic) and 3.0 (genomic), Gencode 34). All synonymous SNP types were excluded from the study.

The quality of FASTQ files was analyzed using FastQC, version 0.11 .5 -cegat [33]. The plots were created with ggplot2 [34] in R version 3.6.1 [35]. When interpreting the data of bioinformatic analysis, the combined annotated - dependent depletion (CADD) was calculated for each identified SNP of the LEPR gene [36], and the software products FILTUS [37], SeqVISTA [38], Mutation assessor [39] were used.

Statistical processing of the results using parametric and nonparametric methods included: analysis of variance with the calculation of the Student's test (t); Spearman correlation analysis with calculation of Spearman's rank correlation coefficient ( $\rho)$, multiple discriminant analysis with the calculation of the coefficients of the standardized canonical discriminant function $\left(\mathrm{Ci}_{\mathrm{MUO}}\right)$.

The critical value of the statistical significance level $(P)$ for all types of analysis was taken at the level of $P<0.05$ (5\%). Statistical processing of the results was performed using Microsoft Excel (Office Home Business 2KB4Y6H9DB-BM47K-749PV-PG3KT) and Statistica 6.1 software (StatSoftInc, no. AGAR909E415822FA).

\section{Results}

The mean age of patients in the main and control groups was $12.14 \pm 0.08$ and $12.34 \pm 0.76$, respectively. The proportion of boys in the main group was $57.14 \pm 6.61 \%$, while in the control group, the proportion of boys in the study population was $47.17 \pm 6.86 \%, P \geq 0.05$.

As a result of molecular immunological studies, the serum levels of pro-inflammatory and anti-inflammatory adipokines and cytokine IL-6 was detected in obesity (Table 1).

In obese children, regardless of the sex and obesity phenotype, there was a significant increase in serum leptin levels $(P<0.05)$. At the same time, changes in the leptin concentration moved towards being sex-dependent with the development of metabolic disorders. In males of both study groups, the level of leptin did not differ from each other, and in females with MUO, the concentration of leptin was 1.5 times higher than that in the representatives with $\mathrm{MHO}$ and amounted to $47.8 \pm 4.4 \mathrm{ng} / \mathrm{ml}$.
Table 1. Mean concentration $\left(\mathrm{M} \pm \mathrm{m}\right.$ ) and median $(\mathrm{Me})^{*}$ of serum inflammatory markers values in children with different obesity phenotypes

\begin{tabular}{|c|c|c|c|c|c|c|}
\hline \multirow[t]{2}{*}{ Indicator, units } & \multirow[t]{2}{*}{$\begin{array}{l}\text { Reference } \\
\text { values }\end{array}$} & \multicolumn{2}{|c|}{$\begin{array}{l}\text { Patients with MUO } \\
(n=56)\end{array}$} & \multicolumn{2}{|c|}{$\begin{array}{l}\text { Patients with MHO } \\
(n=53)\end{array}$} & \multirow[t]{2}{*}{$\mathbf{P}$} \\
\hline & & $M \pm m$ & $\mathrm{Me}$ & $M \pm m$ & Me & \\
\hline $\mathrm{IL}-1 \beta, \mathrm{pg} / \mathrm{ml}$ & $0-5$ & $2.5 \pm 0.3$ & 1.9 & $1.8 \pm 0.7$ & 1.7 & $>0.05$ \\
\hline IL-6, pg/ml & $1.5-7.0$ & $7.4 \pm 0.5$ & 6.8 & $4.3 \pm 0.3$ & 3.4 & $<0.05$ \\
\hline C-reactive protein, $\mathrm{mg} / \mathrm{L}$ & $0-5$ & $2.6 \pm 0.7$ & 2.3 & $2.1 \pm 0.4$ & 2 & $>0.05$ \\
\hline \multicolumn{7}{|l|}{ Leptin, ng/ml } \\
\hline Boys & $2.0-5.6$ & $29.3 \pm 8.9$ & 25 & $26.0 \pm 6.4$ & 24.4 & $>0.05$ \\
\hline Girls & $3.7-11.1$ & $47.8 \pm 4.4$ & 45.2 & $32.5 \pm 4.3$ & 28.5 & $<0.05$ \\
\hline Adiponectin, $\mu \mathrm{g} / \mathrm{ml}$ & $\geq 10$ & $3.9 \pm 0.8$ & 3.1 & $7.7 \pm 2.4$ & 6.5 & $<0.05$ \\
\hline
\end{tabular}

*: Me with $95 \% \mathrm{Cl}$ median

Children with the MUO phenotype differed from MHO by a significantly lower serum level of adiponectin, which was $3.9 \pm 0.8 \mu \mathrm{g} / \mathrm{ml}$ versus $7.7 \pm 2.4 \mu \mathrm{g} / \mathrm{ml}(P<0.05)$.

One of the most important differences in the cytokine status of obesity phenotypes was the level of IL-6. In the MUO phenotype, a significantly higher serum concentration of IL-6 was observed reaching $7.4 \pm 0.5 \mathrm{pg} / \mathrm{ml}$, than in the $\mathrm{MHO}$ phenotype $(4.3 \pm 0.3 \mathrm{pg} / \mathrm{ml}, \mathrm{P}<0.05)$. At the same time, the serum levels of IL- $1 \beta$ and CRP in the main and control groups corresponded to the reference values and did not differ statistically from each other.

As a result of NGS, 10 types of SNP in the LEPR gene were identified among 35 obese children: rs3790435, rs1137100, rs2186248, rs70940803, rs79639154, rs1359482195, rs1137101, rs1805094, rs13306520, rs13306522. Multiple discriminant analysis with the $\mathrm{Ci}_{\text {MUo }}$ calculation showed the greatest contribution to the development of MUO of the following two SNPs: rs3790435 $\left(\mathrm{Ci}_{\text {MUO }}=0.939\right), \mathrm{rs} 2186248\left(\mathrm{Ci}_{\text {MUO }}=0.862\right), \mathrm{P}<0.05$. In obese children, the incidence of SNP rs3790435 was $71.4 \%$, SNP rs2186248 - $91.4 \%$.

The study on the role of the LEPR gene SNP in various phenotypes of obesity formation demonstrated the following results. The presence of the "wild" CC genotype rs3790435 was more common in children with $\mathrm{MHO}$ (52.9\%), and less often - in children with MUO (16.7 \%), P < 0.05 .

Meanwhile, the "wild" CC genotype rs2186248 was significantly more often identified in the group of children with MUO (100\%), and less often - in the group of children with $\mathrm{MHO}(88.2 \%), \mathrm{P}<0.05$.

23 factors of the clinical, immunological and genetic parameters analyzed were found to be significantly associated with MUO $(P<0.05)$. Among them, according to the strength of relationship with the risk of MUO, 3 groups were distinguished.

1) Highly significant factors $(0.7 \leq|\rho|<1)$ : the level of basal insulinemia $(\rho=0.72 ; P<0.001)$; serum IL-6 level ( $\rho=0.7 ; P<0.001)$ and the presence of the LEPR gene SNP rs3790435 ( $\rho=0.7 ; P<0.001)$.

2) Moderately significant factors $(0.3 \leq|\rho|<0.7)$ : daily consumption of red meat, sausages, potatoes, rice, margarine, sugary drinks $(\rho=0.52 ; P<0.001)$; duration of non-academic time spent at the computer/TV $(\rho=0.5$; $P<0.001)$; fast food intake $(\rho=0.47 ; P<0.001)$; family history of metabolic syndrome $(\rho=0.45 ; P<0.001)$; early introduction of complementary foods $(\rho=0.38$; $P<0.001)$; serving size (in the child's palms) $(\rho=0.37$; $P<0.001)$; age norms for puberty timing violation 
( $\rho=0.35 ; P=0.001)$; child's age at the time of examination $(\rho=0.33 ; P=0.001)$; daily consumption of up to $2-3$ servings of fresh vegetables and fruits $(\rho=-0.32$; $P=0.001)$; pneumonia in a past medical history in puberty ( $\rho=0.3 ; P=0.001$ ).

3) The least significant factors $(0<|\rho|<0.3)$ : the presence of pyoderma $(\rho=0.29 ; P=0.003)$; acantosis nigricans $(\rho=0.29$; $P=0.003)$; hyperleptinemia ( $\rho=0.28 ; P=0.003$ ); serum adiponectin levels ( $\rho=-0.27 ; P=0.007)$; frequency of physical activity $(\rho=-0.26 ; P=0.006)$; level of physical development of a child in percentiles $(\rho=0.26 ; P=0.006)$; pathological antenatal period $(\rho=0.26 ; P=0.006) ;$ LEPR gene SNP rs2186248 ( $\rho=0.25 ; P=0.006)$; being overweight at an early age $(\rho=0.21 ; P=0.031)$; prevalence of fast food in diets $(\rho=0.21 ; P=0.028)$.

The patients with the LEPR gene SNP rs3790435 was found to have a 17 times higher chance of developing meta-inflammation associated with increased IL-6 serum levels than those without this SNP of the LEPR gene $(\mathrm{OR}=17.11 ; 95 \% \mathrm{Cl} 2.8-20.4), \mathrm{P} \leq 0.05$.

\section{Discussion}

The studied factors relating to the lifestyle (the level of physical development of a child in percentiles, the frequency of physical activity, the duration of non-academic time spent at the computer/TV) and inappropriate nutrition (duration of food intake, period of introducing complementary foods, lack of daily consumption of up to 2-3 serving of fresh vegetables and fruits, serving size and daily consumption of red meat, sausages, potatoes, rice, margarine, sugary drinks, fast food) demonstrate a moderate association with MUO and confirm the data of the previous studies on the importance of physical activity and nutritional intervention in the prevention of metabolic complications $[4,40]$. In contrast to the previous works, the gradient presentation of the results of rank correlation analysis in our study contains data on the diagnostic significance of not only modifiable environmental factors, but also immunological, molecular genetic markers associated with the LEPR gene SNPs and causing the formation of meta-inflammation in MUO.

Our data indicate a strong association between MUO and the level of IL- 6 and a weak association between MUO and the level of leptinemia in girls (no significant changes in boys) and the serum adiponectin concentration in both sexes. This serum content of pro-inflammatory cytokines indicates that meta-inflammation in obesity is IL-6-dependent. This is probably due to the fact that about $35 \%$ of the circulating IL- 6 pool is produced in adipose tissue and is responsible for its macrophage infiltration [41-43]. Corina Piercean et al. [44] also found an increase in the secreted IL-6 and leptin in saliva during obesity in children, but unlike our work, despite such an advantage as minimally invasive selection of research material, they did not take into account gender division into subgroups in the study of the level of leptinemia, as well as data on the presence or absence of inflammatory processes in the oral cavity in the examined children. The increased concentration of IL- 6 in children with MUO, in our opinion, not only reflects the activity of meta-inflammation, but also carries the risk of developing insulin resistance, since IL-6, in addition to its pro-inflam- matory effect, has an inhibitory effect on insulin-associated signaling pathways, in particular, in hepatocytes [45]. In addition, IL-6 in combination with TGF- $\beta$ ensures the differentiation of naive $\mathrm{CD} 4^{+} \mathrm{T}$-cells into $\mathrm{Th}_{17}$-cells, and inhibits TGF- $\beta$-stimulated differentiation of Treg-cells [46]. Namely, IL-6-mediated imbalance in $\mathrm{Th}_{17} / T_{\text {reg-cells contributes to }}$ the development of autoimmune and chronic inflammatory diseases [47].

We present data on the relationship between two SNPs (rs3790435, rs2186248) of the LEPR gene, which were characterized by a high frequency of occurrence in the cohort of obese patients $(71.4 \%$ and $91.4 \%$ of individuals, respectively) and the risk of MUO formation. One of them, the LEPR gene SNP rs3790435, was previously described by Juan Li et al. [48] being associated with the development of some features of the obesity course. As a study result, Juan $\mathrm{Li}$ et al. found that the presence of the CC genotype rs3790435 in obese individuals reduced the risk of obstructive sleep apnea syndrome compared to people with the TT/ CT genotype. At the same time, our results confirm the data of Juan Li et al. about the higher frequency of the CC genotype rs3790435 of the LEPR gene in the cohort of children with the $\mathrm{MHO}$ phenotype. In addition, we have demonstrated for the first time a strong relationship between the LEPR gene SNP rs3790435 and the risk of MUO formation, and IL-6-dependent meta-inflammation. An important result of our work is the discovery of the previously undescribed LEPR gene SNP rs2186248, which was found in $91.4 \%$ of the examined obese children, being characterized by the weak correlation with the formation of MUO.

\section{Conclusions}

1. The triggering factors for the risk of MUO in association with a genetic predisposition require initial modification in children through a reduction in the duration of non-academic time spent at a computer/TV and daily consumption of red meat, sausages, potatoes, rice, margarine, and sugary drinks.

2. Meta-inflammation in MUO is IL-6-dependent. Pro-inflammatory IL-6 is one of the potential mediators linking obesity-induced meta-inflammation with insulin and leptin resistance.

3. Among the 10 SNPs of the LEPR gene that we identified, two of them are associated with the MUO phenotype development. SNP rs3790435 of the LEPR gene, identified in $71.4 \%$ of obese children examined, is characterized by the strong association with the MUO phenotype. The CT genotype rs3790435 is the risk factor for the development of MUO. Children with the CT SNP rs3790435 genotype of the LEPR gene have the 17 times higher chance of developing IL-6-dependent meta-inflammation than children with the CC genotype. The newly identified SNP rs2186248 of the LEPR gene is weakly associated with the MUO phenotype. However, its TT genotype is significantly more common in children with the MUO phenotype.

Prospects for further research. Our results require further study and confirmation in broader patient populations, which will give us a better and more complete understanding of the relationship between the LEPR gene polymorphism and the MUO risk. 


\section{Funding}

The work is a fragment of the research work of the Dnipro State Medical University "Predicting the development of childhood diseases associated with civilization", state registration No. $0120 U 101324$

The study was carried out according to the budget program of the Code of program classification of expenses and crediting 2301020 "Scientific and technical activities in the field of health care", funded by the Ministry of Health of Ukraine from the state budget.

Conflict of interest: authors have no conflict of interest.

Конфмікт інтересів: віАсутній.

Надійшла до редакції / Received: 21.03.2021

Після Аоопрацювання / Revised: 12.04.2021

Прийнято Ао Аруку / Accepted: 23.04.2021

Information about authors:

Abaturov A. E., MD, PhD, DSc, Professor, Head of the Department of Pediatrics 1 and Medical Genetics, Dnipro State Medical University, Dnipro, Ukraine.

ORCID ID: 0000-0001-6291-5386

Nikulina A. 0., MD, PhD, Associate Professor of the Department of Pediatrics 1 and Medical Genetics, Dnipro State Medical University, Dnipro, Ukraine. ORCID ID: 0000-0002-8617-9341

\section{Відомості про авторів}

Абатуров 0. Є., А-р меА. наук, професор, зав. каф. педіатрії 1 та медичної генетики, Аніпровський Аержавний медичний університет, Україна.

Нікуліна А. О., канА. меА. наук, доцент каф. педіатрії 1 та медичної генетики, Аніпровський Аержавний меАичний університет, Україна.

\section{Сведения об авторах:}

Абатуров А. Е., А-р меА. наук, профессор, зав. каф. педиатрии 1 и медицинской генетики, Анепровский государственный медицинский университет, Украина.

Никулина А. А., канА. меА. наук, Аоцент каф. педиатрии 1 и медицинской генетики, Анепровский государственный медицинский университет, Украина.

\section{References}

[1] Lobstein, T., \& Brinsden, H. (2019). Atlas of Childhood Obesity. World Obesity Federation. https://data.worldobesity.org/publications/11996-Childhood-Obesity-Atlas-Report-ART-V2.pdf

[2] Genovesi, S., Antolini, L., Orlando, A., Gilardini, L., Bertoli, S., Giussani, M., Invitti, C., Nava, E., Battaglino, M. G., Leone, A., Valsecchi, M. G., \& Parati, G. (2020). Cardiovascular Risk Factors Associated With the Metabolically Healthy Obese (MHO) Phenotype Compared to the Metabolically Unhealthy Obese (MUO) Phenotype in Children. Frontiers in Endocrinology, 11, Article 27. https://doi.org/10.3389/fendo.2020.00027

[3] Magge, S. N., Goodman, E., Armstrong, S. C., COMMITTEE ON NUTRITION, SECTION ON ENDOCRINOLOGY, \& SECTION ON OBESITY. (2017). The Metabolic Syndrome in Children and Adolescents: Shifting the Focus to Cardiometabolic Risk Factor Clustering. Pediatrics, 140(2), Article e20171603. https://doi.org/10.1542/peds.2017-1603

[4] Expert Panel on Integrated Guidelines for Cardiovascular Health and Risk Reduction in Children and Adolescents, \& National Heart, Lung, and Blood Institute. (2011). Expert Panel on Integrated Guidelines for Cardiovascular Health and Risk Reduction in Children and Adolescents: Summary Report. Pediatrics, 128(Suppl 5), S213-S256. https://doi. org/10.1542/peds.2009-2107C

[5] Abaturov, A., \& Nikulina, A. (2019). Genotype C/C 13910 of the Lactase Gene as a Risk Factor for the Formation of Insulin-Resistant Obesity in Children. Acta Medica, 62(4), 150-155. https://doi. org/10.14712/18059694.2020.4

[6] Elkins, C., Fruh, S., Jones, L., \& Bydalek, K. (2019). Clinical Practice Recommendations for Pediatric Dyslipidemia. Journal of Pediatric Health Care, 33(4), 494-504. https://doi.org/10.1016/i. pedhc.2019.02.009
[7] Vukovic, R., Dos Santos, T. J., Ybarra, M., \& Atar, M. (2019). Children With Metabolically Healthy Obesity: A Review. Frontiers in Endocrinology, 10, Article 865. https://doi.org/10.3389/fendo.2019.00865

[8] Tsatsoulis, A., \& Paschou, S. A. (2020). Metabolically Healthy Obesity: Criteria, Epidemiology, Controversies, and Consequences. Current Obesity Reports, 9(2), 109-120. https://doi.org/10.1007/s13679-020$\underline{00375-0}$

[9] Nunziata, A., Funcke, J. B., Borck, G., von Schnurbein, J., Brandt, S., Lennerz, B., Moepps, B., Gierschik, P., Fischer-Posovszky, P., \& Wabitsch, M. (2018). Functional and Phenotypic Characteristics of Human Leptin Receptor Mutations. Journal of the Endocrine Society, 3(1), 27-41. https://doi.org/10.1210/js.2018-00123

[10] Voigtmann, F., Wolf, P., Landgraf, K., Stein, R., Kratzsch, J., Schmitz, S Abou Jamra, R., Blüher, M., Meiler, J., Beck-Sickinger, A. G., Kiess, W., \& Körner, A. (2021). Identification of a novel leptin receptor (LEPR) variant and proof of functional relevance directing treatment decisions in patients with morbid obesity. Metabolism, 116, Article 154438. https:// doi.org/10.1016/j.metabol.2020.154438

[11] Li, J., Yang, S., Jiao, X., Yang, Y., Sun, H., Zhang, M., Yang, Y., Qin, Y., \& Wei, Y. (2019). Targeted Sequencing Analysis of the Leptin Receptor Gene Identifies Variants Associated with Obstructive Sleep Apnoea in Chinese Han Population. Lung, 197(5), 577-584. https://doi. org/10.1007/s00408-019-00254-z

[12] Rojano-Rodriguez, M. E., Beristain-Hernandez, J. L., Zavaleta-Villa, B., Maravilla, P., Romero-Valdovinos, M., \& Olivo-Diaz, A. (2016). Leptin receptor gene polymorphisms and morbid obesity in Mexican patients. Hereditas, 153, Article 2. https://doi.org/10.1186/s41065-016-0006-0

[13] Manriquez, V., Aviles, J., Salazar, L., Saavedra, N., Seron, P., Lanas, F., Fajardo, C. M., Hirata, M. H., Hirata, R., \& Cerda, A. (2018). Polymorphisms in Genes Involved in the Leptin-Melanocortin Pathway are Associated with Obesity-Related Cardiometabolic Alterations in a Southern Chilean Population. Molecular Diagnosis \& Therapy, 22(1), 101-113. https://doi.org/10.1007/s40291-017-0306-8

[14] Wu, J., Zhuo, Q., Tian, Y., Piao, J., \& Yang, X. (2017). [Relationship of diabetes mellitus in older Han adults in China with leptin receptor gene rs 1137100 and rs1137101 polymorphrism]. Wei sheng yan jiu, 46(3), 384-388.

[15] Almeida, S. M., Furtado, J. M., Mascarenhas, P., Ferraz, M. E., Ferreira, J. C., Monteiro, M. P., Vilanova, M., \& Ferraz, F. P. (2018) Association between LEPR, FTO, MC4R, and PPARG-2 polymorphisms with obesity traits and metabolic phenotypes in school-aged children. Endocrine, 60(3), 466-478. https://doi.org/10.1007/s12020-018-1587-3

[16] Almandil, N. B., Lodhi, R. J., Ren, H., Besag, F., Rossolatos, D., Ohlsen, R., Slomp, C., Lapetina, D. L., Plazzotta, G., Murray, M. L., Al-Sulaiman, A. A., Gringras, P., Wong, I., \& Aitchison, K. J. (2018). Associations between the LEP -2548G/A Promoter and Baseline Weight and between LEPR GIn223Arg and Lys656Asn Variants and Change in BMI z Scores in Arab Children and Adolescents Treated with Risperidone. Molecular Neuropsychiatry, 4(2), 111-117. https:/l doi.org/10.1159/000490463

[17] Ren, D., Xu, J. H., Bi, Y., Zhang, Z., Zhang, R., Li, Y., Hu, J., Guo, Z. Niu, W., Yang, F., Li, W., Xu, Y., He, L., Yu, T., Wu, J., Li, X., Du, J., \& $\mathrm{He}, \mathrm{G}$. (2019). Association study between LEPR, MC4R polymorphisms and overweight/obesity in Chinese Han adolescents. Gene, 692, 54-59. https://doi.org/10.1016/i.gene.2018.12.073

[18] Fairbrother, U., Kidd, E., Malagamuwa, T., \& Walley, A. (2018). Genetics of Severe Obesity. Current Diabetes Reports, 18(10), Article 85. https:// doi.org/10.1007/s11892-018-1053-X

[19] Dos Santos Rocha, A., de Cássia Ribeiro-Silva, R., Nunes de Oliveira Costa, G., Alexandrina Figueiredo, C., Cunha Rodrigues, L., Maria Alvim Matos, S., Leovigildo Fiaccone, R., Oliveira, P. R. Alves-Santos, N. H., Blanton, R. E., \& Lima Barreto, M. (2018). Food Consumption as a Modifier of the Association between LEPR Gene Variants and Excess Body Weight in Children and Adolescents: A Study of the SCAALA Cohort. Nutrients, 10(8), Article 1117. https:// doi.org/10.3390/nu10081117

[20] Furusawa, T., Naka, I., Yamauchi, T., Natsuhara, K., Kimura, R., Nakazawa, M., Ishida, T., Inaoka, T., Matsumura, Y., Ataka, Y., Nishida, N., Tsuchiya, N., Ohtsuka, R., \& Ohashi, J. (2010). The Q223R polymorphism in LEPR is associated with obesity in Pacific Islanders. Human Genetics, 127(3), 287-294. https://doi.org/10.1007/s00439-009-0768-9

[21] Abaturov, A., \& Nikulina, A. (2021). The Role of Leptin Receptor Gene Polymorphism in the Formation of Insulin Resistance in Children. Metabolism, 116, Article 154672. https://doi.org/10.1016/j. metabol.2020.154672

[22] WHO Multicentre Growth Reference Study Group. (2006). WHO Child Growth Standards based on length/height, weight and age. Acta Paediatrica, 95(S450), 76-85. https://doi.org/10.1111/i.1651-2227.2006. tb02378.x

[23] American Diabetes Association. (2019). 2. Classification and Diagnosis of Diabetes: Standards of Medical Care in Diabetes-2019. Diabetes Care, 42(Suppl. 1), S13-S28. https://doi.org/10.2337/dc19-S002 
[24] Alberti, K. G., Zimmet, P., \& Shaw, J. (2007). International Diabetes Federation: a consensus on Type 2 diabetes prevention. Diabetic Medicine, 24(5), 451-463. https://doi.org/10.1111/j.14645491.2007.02157.x

[25] Weihe, P., \& Weihrauch-Blüher, S. (2019). Metabolic Syndrome in Children and Adolescents: Diagnostic Criteria, Therapeutic Options and Perspectives. Current Obesity Reports, 8(4), 472-479. https://doi. org/10.1007/s13679-019-00357-x

[26] Ranasinghe, P., Jayawardena, R., Gamage, N., Pujitha Wickramasinghe, V., \& Hills, A. P. (2021). The range of non-traditional anthropometric parameters to define obesity and obesity-related disease in children: a systematic review. European Journal of Clinical Nutrition, 75(2), 373384. https://doi.org/10.1038/s41430-020-00715-2

[27] Peplies, J., Jiménez-Pavón, D., Savva, S. C., Buck, C., Günther, K. Fraterman, A., Russo, P., lacoviello, L., Veidebaum, T., Tornaritis, M., De Henauw, S., Mårild, S., Molnár, D., Moreno, L. A., Ahrens, W., \& IDEFICS consortium. (2014). Percentiles of fasting serum insulin, glucose, HbA1c and HOMA-IR in pre-pubertal normal weight European children from the IDEFICS cohort. International Journal of Obesity, 38(Suppl. 2), S39-S47. https://doi.org/10.1038/ijo.2014.134

[28] Haugaard, L. K., Baker, J. L., Perng, W., Belfort, M. B., Rifas-Shiman, S. L., Switkowski, K., Oken, E., \& Gillman, M. W. (2016). Growth in Total Height and Its Components and Cardiometabolic Health in Childhood. PLOS ONE, 11(9), Article e0163564. https://doi.org/10.1371/ journal.pone. 0163564

[29] ACMG Board of Directors. (2015). Clinical utility of genetic and genomic services: a position statement of the American College of Medical Genetics and Genomics. Genetics in Medicine, 17(6), 505-507. https:// doi.org/10.1038/gim.2015.41

[30] Jiang, H., Lei, R., Ding, S. W., \& Zhu, S. (2014). Skewer: a fast and accurate adapter trimmer for next-generation sequencing paired-end reads. BMC Bioinformatics, 15, Article 182. https://doi. org/10.1186/1471-2105-15-182

[31] Li, H., \& Durbin, R. (2009). Fast and accurate short read alignment with Burrows-Wheeler transform. Bioinformatics, 25(14), 1754-1760. https://doi.org/10.1093/bioinformatics/btp324

[32] Mose, L. E., Wilkerson, M. D., Hayes, D. N., Perou, C. M., \& Parker, J. S. (2014). ABRA: improved coding indel detection via assembly-based realignment. Bioinformatics, 30(19), 2813-2815. https://doi.org/10.1093/ bioinformatics/btu376

[33] Wingett, S. W., \& Andrews, S. (2018). FastQ Screen: A tool for multi-genome mapping and quality control [version 2; peer review: 4 approved]. F1000Research, 7, Article 1338. https://doi.org/10.12688/ f1000research.15931.2

[34] Wickham, H. (2009). Manipulating data. In ggplot2 (pp. 157-175). Springer. https://doi.org/10.1007/978-0-387-98141-3 g

[35] R-Project. (n.d.). The R Project for Statistical Computing. https:// www.r-project.org/

[36] Rentzsch, P., Witten, D., Cooper, G. M., Shendure, J., \& Kircher, M. (2019). CADD: predicting the deleteriousness of variants throughout the human genome. Nucleic Acids Research, 47(D1), D886-D894. https://doi.org/10.1093/nar/gky1016

[37] Vigeland, M. D., Gjotterud, K. S., \& Selmer, K. K. (2016). FILTUS: a desktop GUI for fast and efficient detection of disease-causing variants, including a novel autozygosity detector. Bioinformatics, 32(10), 1592 1594. https://doi.org/10.1093/bioinformatics/btw046

[38] Hu, Z., Fu, Y., Halees, A. S., Kielbasa, S. M., \& Weng, Z. (2004). SeqVISTA: a new module of integrated computational tools for studying transcriptional regulation. Nucleic Acids Research, 32(Suppl. 2), W235-W241. https://doi.org/10.1093/nar/gkh483

[39] Liu, X., Wu, C., Li, C., \& Boerwinkle, E. (2016). dbNSFP v3.0: A OneStop Database of Functional Predictions and Annotations for Human Nonsynonymous and Splice-Site SNVs. Human Mutation, 37(3), 235241. https://doi.org/10.1002/humu.22932

[40] Ambroszkiewicz, J., Klemarczyk, W., Gajewska, J., Chełchowska, M., Rowicka, G., Ołtarzewski, M., \& Laskowska-Klita, T. (2011). Serum concentration of adipocytokines in prepubertal vegetarian and omnivorous children. Medycyna wieku rozwojowego, 15(3), 326-334.

[41] Han, M. S., White, A., Perry, R. J., Camporez, J. P., Hidalgo, J., Shulman, G. I., \& Davis, R. J. (2020). Regulation of adipose tissue inflammation by interleukin 6. Proceedings of the National Academy of Sciences of the United States of America, 117(6), 2751-2760. https:/l doi.org/10.1073/pnas.1920004117

[42] Wueest, S., \& Konrad, D. (2018). The role of adipocyte-specific IL-6-type cytokine signaling in FFA and leptin release. Adipocyte, 7(3), 226-228. https://doi.org/10.1080/21623945.2018.1493901

[43] Lehrskov, L. L., \& Christensen, R. H. (2019). The role of interleukin-6 in glucose homeostasis and lipid metabolism. Seminars in Immunopathology, 41(4), 491-499. https://doi.org/10.1007/s00281-019-00747-2

[44] Pîrsean, C., Neguț, C., Stefan-van Staden, R. I., Dinu-Pirvu, C. E., Armean, P., \& Udeanu, D. I. (2019). The salivary levels of leptin and interleukin- 6 as potential inflammatory markers in children obesity.
PLOS ONE, 14(1), Article e0210288. https://doi.org/10.1371/journal. pone.0210288

[45] Zhang, Y., Li, C., Zhang, W., Zheng, X., \& Chen, X. (2020). Decreased Insulin Resistance by Myo-Inositol Is Associated with Suppressed Interleukin 6/Phospho-STAT3 Signaling in a Rat Polycystic Ovary Syndrome Model. Journal of Medicinal Food, 23(4), 375-387. https:// doi.org/10.1089/jmf.2019.4580

[46] Kimura, A., \& Kishimoto, T. (2010). IL-6: regulator of Treg/Th17 balance. European Journal of Immunology, 40(7), 1830-1835. https:// doi.org/10.1002/eji.201040391

[47] El-Alameey, I. R., Fadl, N. N., Hameed, E. R., Sherif, L. S., \& Ahmed, H. H. (2015). Clinical Relevance of Transforming Growth Factor- $\beta 1$, Interleukin- 6 and Haptoglobin for Prediction of Obesity Complications in Prepubertal Egyptian Children. Open Access Macedonian Journal of Medical Sciences, 3(1), 105-110. https://doi.org/10.3889/ oamims.2015.017

[48] Li, J., Yang, S., Jiao, X., Yang, Y., Sun, H., Zhang, M., Yang, Y., Qin, Y., \& Wei, Y. (2019). Targeted Sequencing Analysis of the Leptin Receptor Gene Identifies Variants Associated with Obstructive Sleep Apnoea in Chinese Han Population. Lung, 197(5), 577-584. https://doi. org/10.1007/s00408-019-00254-z 